\title{
The Utility of Purge and Recovery Testing in Ground-Gas Flux Risk Assessment
}

\author{
Arthur N. Nwachukwu ${ }^{1,2}$, Ndidiamaka N. Eluwa ${ }^{2}$, Clementina U. Uwa ${ }^{3}$, Nkechinyere V. Nwachukwu ${ }^{4}$ \\ ${ }^{1}$ Williamson Research Centre for Molecular Environmental Sciences School of Earth, Atmospheric and Environmental Sciences, The \\ University of Manchester, UK, M13 9PL. \\ ${ }^{2}$ Department of Physics, Alex Ekwueme Federal University, Ndufu-Alike Ikwo, Ebonyi state, Nigeria. \\ ${ }^{3}$ Department of Biology, Alex Ekwueme Federal University, Ndufu-Alike Ikwo, Ebonyi State, Nigeria. \\ ${ }^{4}$ Department of Community Medicine, Alex Ekwueme Federal Teaching Hospital, Abakaliki, Ebonyi State, Nigeria.
}

\begin{abstract}
Purge and recovery testing is a novel method for measuring ground-gas flux. This method has been tested with Gasclam in boreholes at two landfill sites at southern Manchester, UK. The recovery rate of individual gases was used to predict when and at which concentration they would reach the unmonitored receptors. For example, at site 1 in borehole $2, \mathrm{CH}_{4}$ and $\mathrm{CO}_{2}$ had concentrations of $22 \%$ and $4 \%$, respectively before purging in September (2010); meanwhile in May (2011), it recorded $23 \%$ and $4.4 \%$, respectively. Whereas after purging, recovery was occurred within $32 \mathrm{hrs}$ and $14 \mathrm{hrs}$, respectively and $23 \%$ of $\mathrm{CH}_{4}$ and $4.4 \%$ of $\mathrm{CO}_{2}$ were recovered in $52 \mathrm{hrs}$ and $27 \mathrm{hrs}$ respectively after purging in summer time. This implies that $\mathrm{CH}_{4}$ and $\mathrm{CO}_{2}$ concentrations recovery in this borehole was faster in September 2010 than in May 2011. The recovery time of the investigated gases was varied from the length of site visit to over a day. It also varied with season and site. Soil permeability and gas production rate are suspected to be responsible for variations in gas recharge rate. In general, the recovery profiles of VOC were very different from those of $\mathrm{CH}_{4}$ and $\mathrm{CO}_{2}$. VOC tended to recover in no time, indicating that they could get to the receptor much faster compared to other gases, thereby posing more danger. The reproducibility of the gases was not consistent due to their low concentrations.
\end{abstract}

Keywords: Gasclam, Flux, Concentration, Local risk, Global risk, Migration rate.

\section{INTRODUCTION}

Ground-gas monitoring is an important aspect of the investigation and management of contaminated sites, as the data is critical to the process of risk assessment (Morris et al., 2008; Friedrich and Trois, 2011; Ashraf et al., 2014; Nagamori et al., 2016; Talbot and Cards, 2019). Ground-gas concentration and its flux are the two the most important parameters in ground-gas risk assessment (Jewell and Hallam, 2012; British Standard 8576, (2013); Nwachukwu and Anonye, 2013). This is because the concentration is used to assess their local risks (explosion and asphyxiation) and flux, andt heir global risk (warming) (Boyle and Witherington, 2007; Katy et al., 2009; Boucher et al., 2009; Wilson et al., 2017; Wilson et al., 2018; Feuyit et al., 2019).

Until 1996, only local risks of explosion and asphyxiation were assessed (Wilson and Cards, 1999), and these were done in terms of concentrations only. However, concentration is not necessarily measured at the source since it often does not constitute danger to human health there until it migrates to the receptor. Ideally, they should be measured at the receptor. Generally, there are often multiple receptors and it is rarely possible to monitor all of them. Therefore, there is a requirement to monitor the flux to determine when and at what concentration ground-gas will get to the unmonitored receptors. Boult et al., (2011) supported this hypothesis by clearly illustrating the inadequacy of concentration alone using high-resolution data of both ground-gas concentration and flux collected from the same borehole. They recommended that both variables should be incorporated into a Conceptual Site Model for effective risk assessment.
Ground-gas flux is currently inferred or generated from gas accumulated in a borehole during the intersampling period (Gal et al., 2019); therefore, it is not instantaneous flux that is measured. If accumulation occurred without gas loss, this measurement of flux may be useful as an average over the sampling period. However, a borehole may have an unknown gas exchange (variable inflow and outflow of gas); if this is the case, the inferred flux may not always be representative of that of the accumulated gas (Boyle and Witherington, 2007; Levintal et al., 2020). Also, the flux measured may be an artefact of the intersampling period. This is because the number of times a borehole is monitored determines the magnitude of flux that would be measured from that borehole. For example, the higher the sampling frequency, the lower the measured ground-gas fluxes since it would take sufficient time for gas pressure to recover.

The capability to make high frequency concentration measurements using the Gasclam allows for a more reliable measurement of ground-gas flux (Morris et al., 2008; Boult et al., 2011; Teasdale et al., 2014). The method is analogous to those used in hydrogeology. While hydrogeologists use this test in characterizing aquifer productivity in which the fluid level in a borehole is perturbed and the recovery period is monitored (Wilson et al., 2006; Nwachukwu and Anonye, 2013); in our case, the fluid is ground-gas. With time-series gas concentration data, a similar approach would adopted. By purge and recovery tests (Musbau, 2009; Acumen and Ggs, 2018), characterization of individual borehole recovery could be identified from which production and /or migration rate can be quantified. 
This work aims to investigate the potentiality of using purge and recovery tests to determine the recharge rate of the gases for effective ground-gas flux risk assessment. To verify whether such tests might be useful, there is a requirement to determine the groundgas recovery on a reasonable timescale (relative to the length of a site visit). Also, it is essential to determine if ground-gas recovery profile is reproducible. This will be done to determine if the test would give the same recovery profile when repeated on the same borehole. Finally, a comparison between the purge and the recovery profiles of ground-gases $\left(\mathrm{CH}_{4}\right.$ and $\left.\mathrm{CO}_{2}\right)$ and Volatile Organic Compounds (VOCs) will be done.

\section{MATERIALS AND METHODS}

To achieve the aim of the study, the recovery profiles of the ground-gases need to be determined. To determine the recovery profile of individual ground-gas the Gasclam was used (Nwachukwu et al., 2018; Nwachukwu and Uwa, 2018), a small $\mathrm{N}_{2}$ gas cylinder and a flow meter. The Gasclam is designed to fit into a $50 \mathrm{~mm}$ borehole (Nwachukwu and Ugwuanyi, 2012).
The standard headworks are 8" monitoring wells from Stuart wells and must be installed in line as the diagram below (Figure 1). It is important to have the standpipe a maximum of $3 \mathrm{~cm}$ above the base of the headworks as this will ensure the Gasclam will fit under the lid of the cover. The headworks must be concentric to the standpipe for the Gasclam to be housed correctly.

In this work, two southern Manchester landfill sites were investigated by monitoring two selected boreholes per site. The boreholes in site 1 are $90 \mathrm{~m}$ deep each, while those of site 2 are $7.50 \mathrm{~m}$ each. The initial measurement of borehole ground-gas concentrations was done using the Gasclam. The borehole volume was calculated from the borehole depth. N2 gas which approximately equal three times $(3 x)$ the volume of the borehole, was injected into the borehole. Gas concentration was checked to be zero or close to zero. The Gasclam was then quickly installed into the borehole to measure the recovery over time (usually every 3 mins). The rate of recovery of individual gases is used to predict when and at what concentration they would get to the unmonitored receptors.

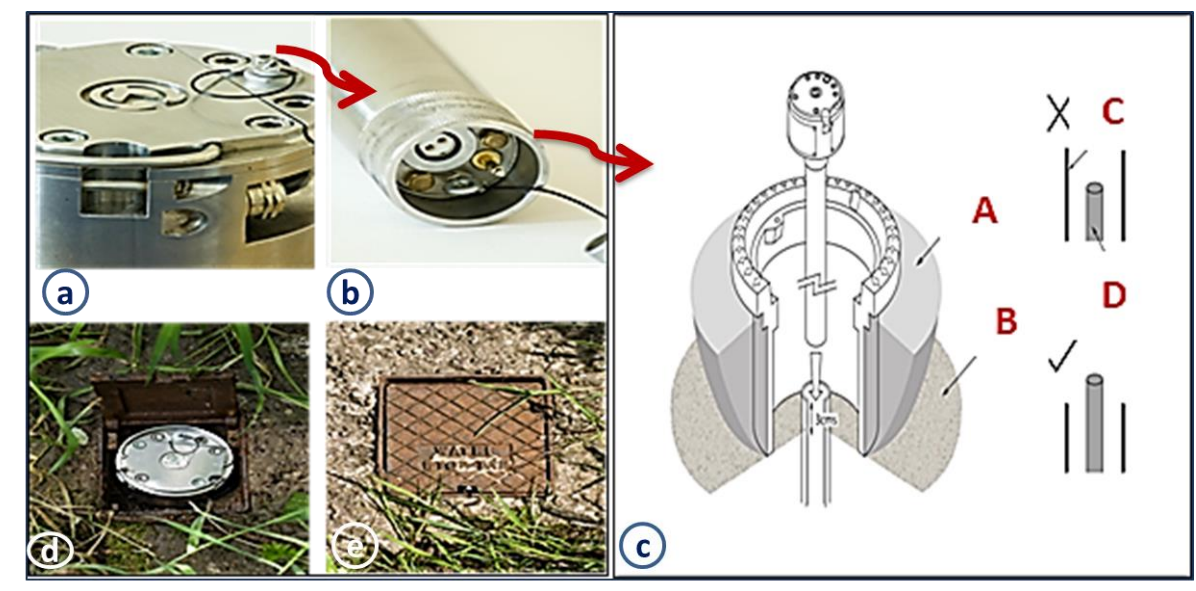

Figure 1: Gasclam In-borehole monitor (LHS) and how to install it in a borehole (RHS); a, GasClam ${ }^{\circ}$; b, close view of GasClam; c, dissected parts of GasClam showing A, concrete collar; B, fitting part to ground; C is protective cover and D standpipe; d-e, fit view to the ground.

\section{Investigated sites}

The two investigated sites are all landfill areas. Site 1 is situated at Guide Lane Audenshaw, Tameside Metropolitan Borough Council, UK. It is a former 'brickworks and associated clay pits' which became a landfill site in the 1940s, for the dumping of domestic, commercial, and industrial waste materials. It ceased to be used as a landfill in about 1975. Residential properties were built on the site during the 1970s. During the late 1990s, gas was found to be leaking into some of the properties (Nwachukwu et al., 2019). A 'venting trench' was installed in 1999 to prevent gas from escaping into the buildings. Though it helped, the problem was not completely resolved as gas leak was not completely abated. Excavations revealed that some of the properties are on top of tipped material and it was formally declared 'contaminated land' (Nwachukwu et al., 2019). Physical site investigation showed the presence of such wastes in the eastern part of the tip, although limited information is available for the remainder of the landfill area. A further landfill site comprising the infilled section of an abandoned railway cutting (southern strip) is situated immediately to the south of the landfill Site and is reported to have been filled with inert wastes only. Site 2, which is located at Ruby Street, Audenshaw, Tameside Metropolitan Borough Council, also comprises of infilled brick pits, which are known to be producing landfill gas and leachate. Records show that this landfill site was infilled with inert, residential, commercial, and industrial waste products until the late 1960s (Nwachukwu and Anonye, 2013). The presence of such wastes at the site has been confirmed by physical site investigation. This landfill site is presently surrounded by council hall. 


\section{RESULTS}

The recharge characteristics of ground-gas $\left(\mathrm{CH}_{4}\right.$ and $\mathrm{CO}_{2}$ ) concentrations over different seasons in the studied sites are presented in Figures $2-5$. Ground-gas recovery rates were used to measure the risk due to their fluxes as they signify the time and concentration they would get to the receptor. Higher-resolution sampling was chosen for purge and recovery testing than for longer-term continuous monitoring because ground-gases have been observed to recover over a short time scale less than 60 mins (Nwachukwu and Anonye, 2013.

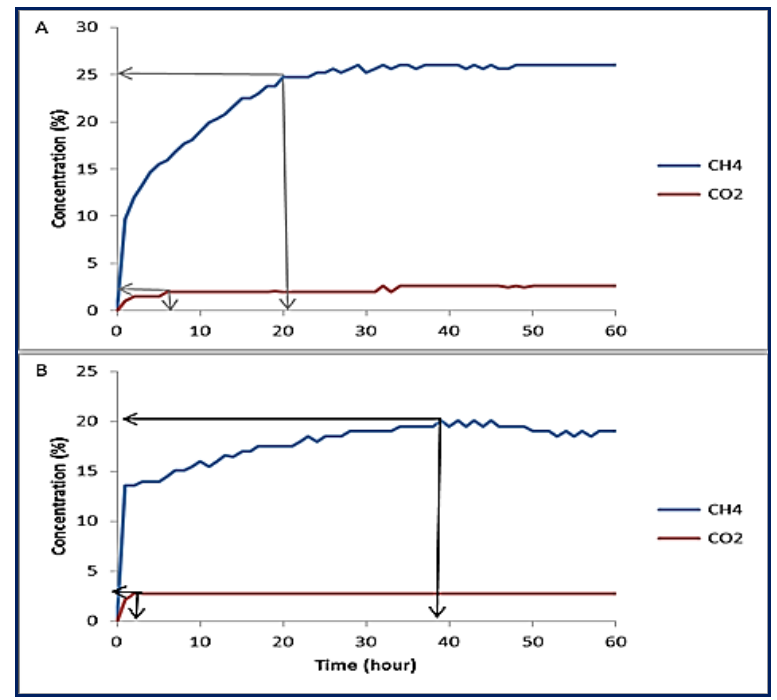

Figure (2): Recharge characteristics of $\mathrm{CH}_{4} / \mathrm{CO}_{2}$ in borehole1at Guide Lane on 08/09/2010 (A) and on 12/05/2011 (B).

The recovery profiles of $\mathrm{CH}_{4} / \mathrm{CO}_{2}$ concentration obtained after purging borehole 1 in September 2010 and May 2011 in Guide Lane are shown by Figures. 2a and $2 \mathrm{~b}$ respectively. Before purging, $\mathrm{CH}_{4}$ and $\mathrm{CO}_{2}$ had concentrations of $25 \%$ and $2.5 \%$ respectively in September 2010 whilst in May 2011; it is $20 \%$ and 3 $\%$ respectively. Figure $2 \mathrm{a}$ shows that $25 \%$ of $\mathrm{CH}_{4}$ and $2.5 \%$ of $\mathrm{CO}_{2}$ were recovered in $22 \mathrm{hrs}$ and $6 \mathrm{hrs}$ respectively whilst figure $2 \mathrm{~b}$ shows $20 \%$ and $3 \%$ of $\mathrm{CH}_{4}$ and $\mathrm{CO}_{2}$ were recovered in $38 \mathrm{hrs}$ and $3 \mathrm{hrs}$ respectively after purging. Both gases remained fairly constant for the remaining period of the test. The figure shows that the recharge of $\mathrm{CH}_{4}$ was faster than that of $\mathrm{CO}_{2}$ in September 2010 than in May 2011. The disparity in $\mathrm{CO}_{2}$ recovery time could be due to siterelated activities during the monitoring period. The concentration seemed to remain the same during the two periods as can be observed from its recovery profiles. Changes in soil permeability may have played a role on the behaviour of the gases over different seasons.

Figure 3 represents the recharge characteristics of $\mathrm{CH}_{4} / \mathrm{CO}_{2}$ concentration conducted in borehole 2 in September 2010 (Figure 3a) and May 2011 (Figure. 3b) at Guide Lane. $\mathrm{CH}_{4}$ and $\mathrm{CO}_{2}$ had concentrations of 22 $\%$ and $4 \%$ respectively before purging in September 2010, and; $23 \%$ and $4.4 \%$ respectively in May 2011 before purging. Whilst $22 \%$ of $\mathrm{CH}_{4}$ and $4 \%$ of $\mathrm{CO}_{2}$ were recovered in $32 \mathrm{hrs}$ and $14 \mathrm{hrs}$ respectively after purging (Figure 3a), $23 \%$ of $\mathrm{CH}_{4}$ and $4.4 \%$ of $\mathrm{CO}_{2}$ were recovered in $52 \mathrm{hrs}$ and $27 \mathrm{hrs}$ respectively after purging (Figure 3b). This implies that the recovery of $\mathrm{CH}_{4}$ and $\mathrm{CO}_{2}$ concentrations in this borehole was faster in September 2010 than in May 2011. The variability in the permeability of the soil during the different periods is again the possible reason for faster recovery of the gases in September (autumn) than in May (spring).

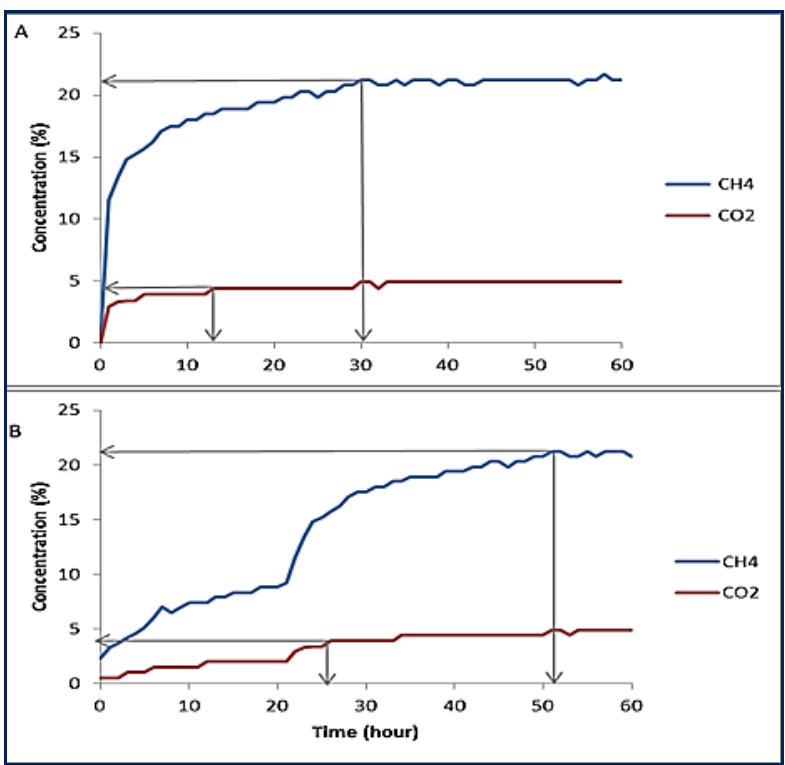

Figure (3): Recharge characteristics of $\mathrm{CH}_{4} / \mathrm{CO}_{2}$ in borehole 2 at Guide Lane on 08/09/2010 (A) and on 12/05/2011 (B).

Figure 4 represents the recharge characteristics of $\mathrm{CH}_{4} / \mathrm{CO}_{2}$ in borehole 1at Ruby Street (site 2) from a purge and recovery test conducted in May 2011 (Figure 4a) and July 2011 (Figure 4b). The concentrations of $\mathrm{CH}_{4}$ and $\mathrm{CO}_{2}$ before purging were recorded in May to be $25 \%$ and $4 \%$ respectively, and in July as $60 \%$ and $32 \%$ respectively. Figure 4 a shows that whilst $25 \%$ of $\mathrm{CH}_{4}$ was recovered in $46 \mathrm{hrs}, 4 \%$ of $\mathrm{CO}_{2}$ was recovered in $18 \mathrm{hrs}$. Figure $4 \mathrm{~b}$, on the other hand, shows $60 \%$ of $\mathrm{CH}_{4}$ and $32 \%$ of $\mathrm{CO}_{2}$ to recover in 12 hrs and $4 \mathrm{hrs}$ respectively. Just like in borehole 2 at Guide Lane, the recharge of $\mathrm{CH}_{4}$ and $\mathrm{CO}_{2}$ concentrations are faster in July 2011 than in May 2011. Again, the behaviour of both gases further validates our earlier finds that the gas recharge rate is often faster during periods of increased soil permeability (like in July) than other times.

The recovery profiles of $\mathrm{CH}_{4} / \mathrm{CO}_{2}$ concentration obtained after conducting purge and recovery tests in borehole 2, at Ruby Street, in May 2011 and July 2011 are shown in Figure 5; where $23 \%$ of $\mathrm{CH}_{4}$ was recovered in $31 \mathrm{hrs}$, whilst $17 \%$ of $\mathrm{CO}_{2}$ was recovered in $26 \mathrm{hrs}$ in July (Figure. 5a).

In May, $22 \%$ of $\mathrm{CH} 4$ was recovered after $44 \mathrm{hrs}$ whilst $3 \%$ of $\mathrm{CO}_{2}$ was recovered after $2 \mathrm{hrs}$ (Figure. $5 b)$. Note that $3 \% \quad \mathrm{CO}_{2}$ concentration which was recovered in $3 \mathrm{hrs}$ in May was recovered in no time in July. 


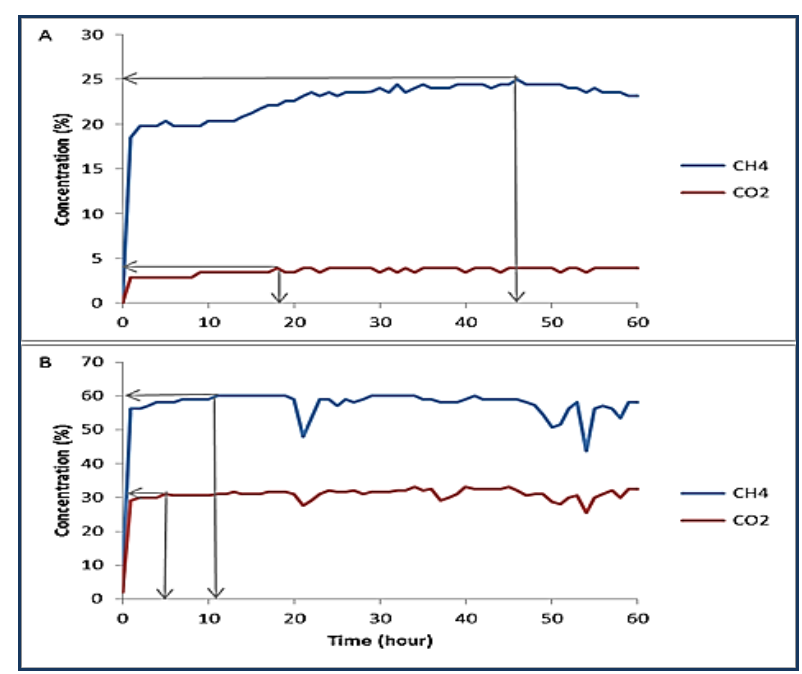

Figure (4): Recharge characteristics of $\mathrm{CH}_{4} / \mathrm{CO}_{2}$ in borehole 1 at Ruby Street on 16/07/2011 (A) and on 12/05/2011 (B).

This a major prove that $\mathrm{CO}_{2}$ also and not only $\mathrm{CH}_{4}$ concentrations displayed faster recovery in July than in May. This further shows that the soil was more permeable in July than in May, thereby allowing for faster recovery of the gases in July than in May.

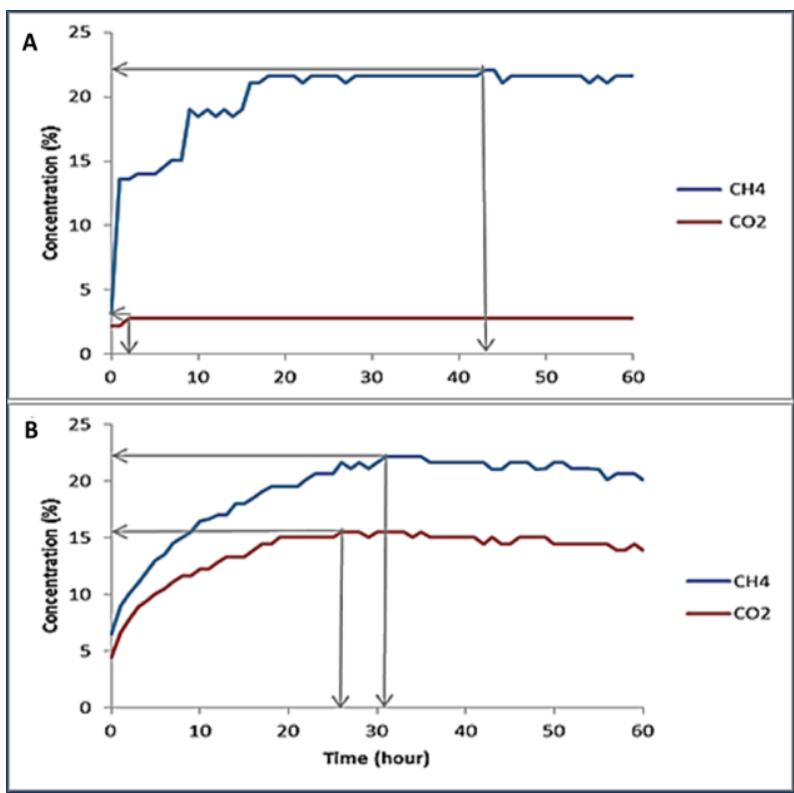

Figure (5): Recharge characteristics of $\mathrm{CH}_{4} / \mathrm{CO}_{2}$ in borehole 2 at Ruby Street on 12/05/2011 (A) and 16/07/2011 (B) in consequence.

To determine if ground-gas recovery is reproducible, the procedure was repeated 2 to 3 times in each borehole. The tests were conducted in two close boreholes at landfill site 1(Guide Lane). The recovery profiles from the purge and recovery tests conducted on 01/09/2011 in borehole 1 are represented by Figures. 6, 7 and 8 for $\mathrm{CH}_{4}, \mathrm{CO}_{2}$, and VOCs respectively; whilst those of borehole 2 conducted on same date are as shown in figures 9 and 10 for $\mathrm{CH}_{4}$ and $\mathrm{CO}_{2}$ only as VOCs displayed zero recoveries. Figures 11 and 12, on the other hand, represent the recovery profiles of $\mathrm{CH}_{4}$ and VOCs in borehole 1 on 11/06/2013 during which $\mathrm{CO}_{2}$ remained zero.

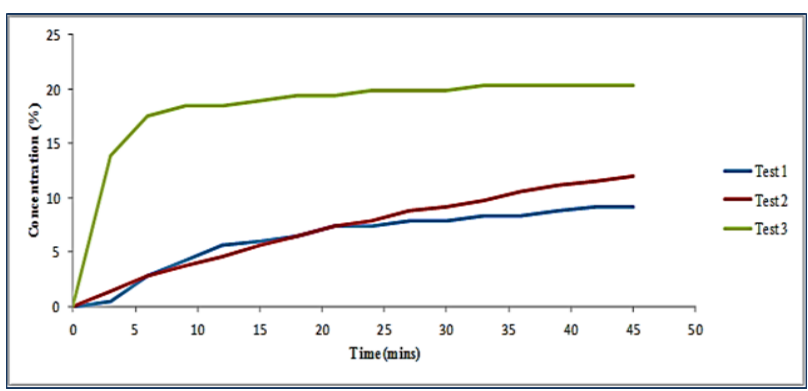

Figure (6): Recovery profiles of $\mathrm{CH}_{4}(\%)$ from three purge and recovery tests conducted in borehole 1 (1/09/2011).

As shown, Figures 6 - 8 represent the recovery profiles of $\mathrm{CH}_{4}, \mathrm{CO}_{2}$, and $\mathrm{VOC}$ respectively for 3 purge and recovery tests in borehole 1 . For $\mathrm{CH}_{4}$, tests 1 and 2 are reproducible and show a slower rate of recovery with the concentration much lower than in test 3 after $40-50$ mins. The recovery profile of test 3 shows that the $\mathrm{CH}_{4}$ concentration rapidly increases for the first 8 mins of recovery and thereafter remaining fairly constant throughout the remaining period of the test. The recovery profiles of each test for $\mathrm{CO}_{2}$ are similar to those of $\mathrm{CH}_{4}$ but the concentrations of $\mathrm{CO}_{2}$ are much lower in comparison. Tests 1 and 2 are reproducible, just like that of methane. The recovery trend of VOC appears to be the opposite of those of $\mathrm{CH}_{4}$ and $\mathrm{CO}_{2}$. For test 1 , the VOC concentration recovered to $4 \mathrm{ppm}$ in no time and then increases to 7 ppm after approximately 4 mins. It then sharply decreases for about $8 \mathrm{mins}$ to $1 \mathrm{ppm}$ and remains constant there for roughly $20 \mathrm{mins}$ before dropping to 0 . In test 2, VOC concentration recovered to $4 \mathrm{ppm}$ as in test 1 , but decreases to $1 \mathrm{ppm}$ after about 6 mins and remained there for roughly 8 mins before dropping to zero. The recovery profile for test 3 shows VOC concentration was dropped from $1 \mathrm{ppm}$ to 0 in fewer than 5 mins.

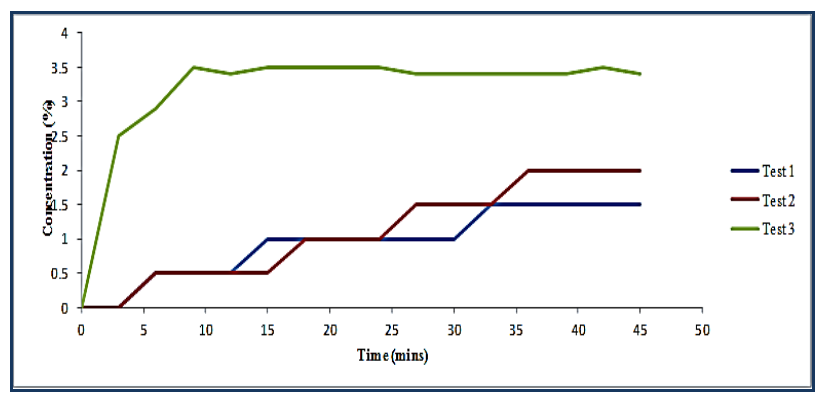

Figure (7): Recovery profiles of $\mathrm{CO}_{2}(\%)$ form three purge and recovery tests conducted in borehole 1 (1/09/2011).

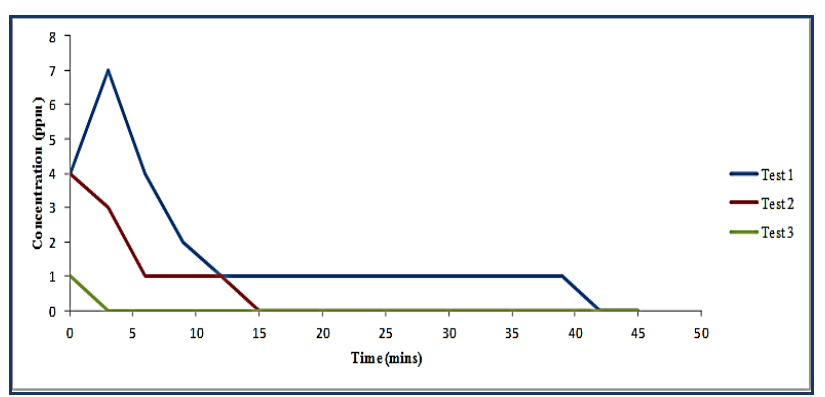

Figure (8): Recovery profiles of VOCs (ppm) from three purge and recovery tests conducted in borehole $1(1 / 09 / 2011)$. 
The recovery profiles of $\mathrm{CH}_{4}$ and $\mathrm{CO}_{2}$ for 3 purge and recovery tests conducted in borehole 2 (Ruby Street) are as shown Figures. 9 and 10, respectively. The recovery profiles of $\mathrm{CH}_{4}$ are similar to those in borehole 1 except that in borehole 1 ; tests 1 and 2 are reproducible while in borehole 2 , tests 2 and 3 are reproducible. In test $1, \mathrm{CO}_{2}$ concentration increased from $0-0.6 \%$ in 3 mins and remained fairly constant for 6 mins and then increased to $1.1 \%$ where it remained constant until the data was downloaded. Tests 2 and 3 displayed the same recovery profiles and therefore are reproducible. There was no recovery profile for $\mathrm{VOC}$ in borehole 2 as the concentration remained zero.

Figure 11 displays the recovery profiles of $\mathrm{CH}_{4}$ for 3 purge and recovery tests conducted on 11/06/2013 in borehole 1 . In test $1, \mathrm{CH}_{4}$ concentration recovered from $0-1.9 \%$ in 3 mins and then fairly increased to $33.3 \%$ and then remained fairly constant there until the end of the test. In test $2, \mathrm{CH}_{4}$ concentration increased from $0-$ $5.7 \%$ in 3 mins and then kept increasing until it got $24.8 \%$ and remained constant there until the data was downloaded. In test 3 , the concentration increased from $0-0.9 \%$ and remained constant for 21 mins before increasing gradually to $10.7 \%$. Although the recovery of $\mathrm{CH}_{4}$ concentration in test 1 is higher than that of test 2; both displayed similar behaviour as can be observed in the shape of their recovery profiles. The recovery profile decreased with an increase in the number of the test (that is, test $1>$ test $2>$ test 3 ). This behaviour of $\mathrm{CH}_{4}$ in this borehole suggests that it is not being replenished continuously from the source and could be depleted with time.

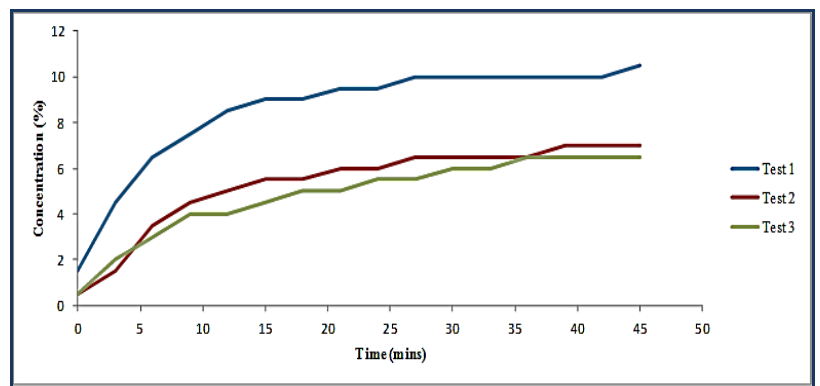

Figure (9): Recovery profiles of $\mathrm{CH}_{4}(\%)$ from three purge and recovery tests conducted in borehole $2(1 / 09 / 2011)$.

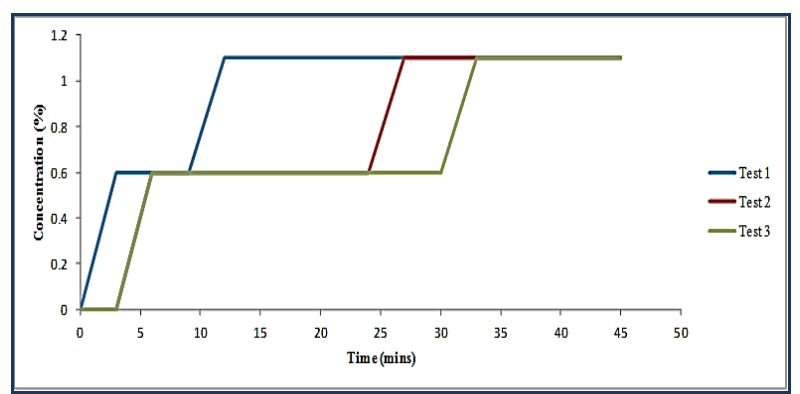

Figure (10): Recovery profiles of $\mathrm{CO}_{2}(\%)$ from three purge and recovery tests conducted in borehole $2(1 / 09 / 2011)$.

The recovery profiles of VOC for three purges and recovery tests conducted on 11/6/2013 in borehole 1 is shown in Figure 12. The first test shows that VOC concentration recovered to $7 \mathrm{ppm}$ in no time and then increased to $21 \mathrm{ppm} 3$ mins later before dropping down to $10 \mathrm{ppm}$. It kept on going down until it got to $3 \mathrm{ppm}$ and remained constant there till the end of the test. Just like the first test, the second and third tests also recovered in no time to $12 \mathrm{ppm}$ and $10 \mathrm{ppm}$ respectively. While tests 1 and 2 displayed the same recovery profile of VOC concentration; that of test 3 is of several other of magnitude higher than that of the first two tests.

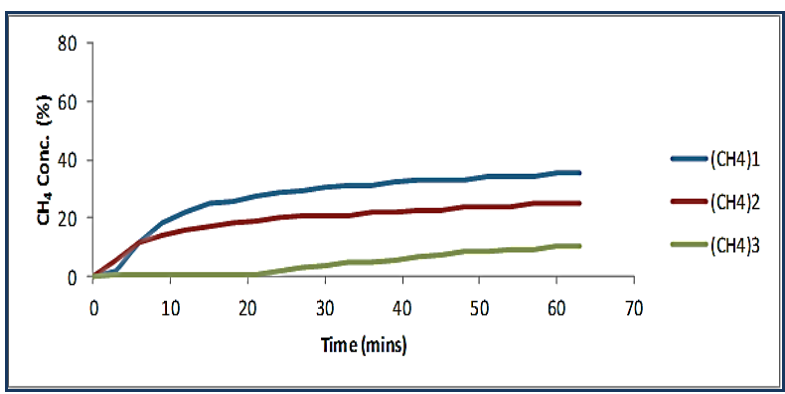

Figure (11): Recovery profiles of $\mathrm{CH}_{4}(\%)$ from three purge and recovery tests conducted in borehole $1(11 / 06 / 2013)$.

Meanwhile, the behaviour of VOCs is exactly the opposite of that exhibited by $\mathrm{CH}_{4}$ which decreased with an increase in the number of purging (Fig. 12). While it can be concluded that tests 1 and 2 were reproducible in this borehole; test 3 did not follow suit. The high concentrations of VOCs recorded after the third test could have been mobilized by the nitrogen gas injected into the borehole. Studies has also shown that the migration of $\mathrm{CH}_{4}$ and $\mathrm{CO}_{2}$ induces the migration of VOCs from contaminated sites (Katy et al., 2009; Felice et al., 2018) and therefore may be another reason.

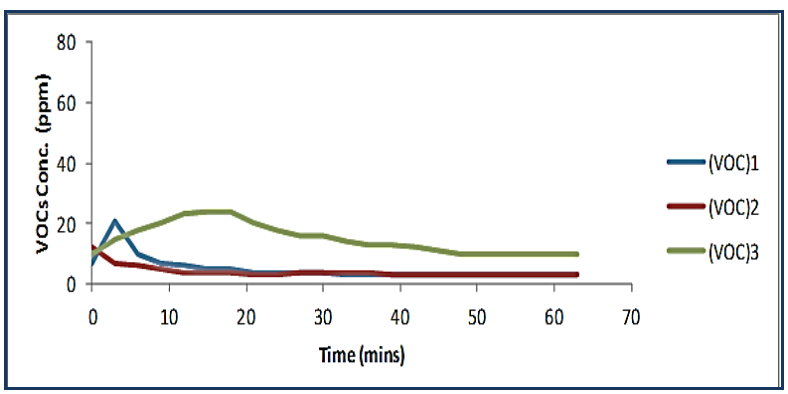

Figure (12): Recovery profiles of VOCs (ppm) from three purge and recovery tests conducted in borehole $1(11 / 06 / 2013)$.

\section{DISCUSSION}

A cursory evaluation of the datasets obtained and presented in Figures 1 - 4 shows that the recovery of $\mathrm{CH}_{4}$ concentration in Guide Lane was faster in September 2010 (autumn) than in May 2011 (spring), whilst in Ruby Street (Site 2), was faster in July 2011 (summer) than in May 2011 (spring). Generally, the $\mathrm{CH}_{4}$ concentration recharge was fastest in July 2011 (summer) amongst all the months considered in the two sites. The rate of $\mathrm{CH}_{4}$ recovery showed a relation with temperature where the recorded range was the highest 
in summer and the lowest in spring (summer > autumn $>$ spring). Seasonal changes in soil perm-eability, which is the ease at which gases, liquids, and plant roots penetrate or pass through bulk mass or a layer of the soil, could have been the reason for the observed behaviours of the gases (Sparks, 2003). This could be the reason for the observed behaviours of the gases. There is often high rainfall (water of very low salinity) in the spring season (March - May), which results in soil leaching thereby reducing soil permeability (Hillel, 2005). This is not the case with the summer (June August) and autumn (September - November) seasons where rainfall is reduced and resulted in an increase in soil permeability. However, in the winter season, the pores of the soil are often blocked by snow that reduced soil permeability (Sparks, 2003). These imply that gas recovery should be faster in summer and autumn than in winter and spring seasons, which validates our findings. In similar studies done by Nwachukwu and Anonye (2013) and Nwachukwu and Nwachukwu (2020), they recorded the same observation in which the effects of changes in season and variations in gas production rate resulted in the variability in and emission of $\mathrm{CH}_{4}$ and $\mathrm{CO}_{2}$ concentration during the monitoring periods of the study.

No purge and recovery test was conducted in the winter; however, the range of recovery implies that it will be lowest in winter during which the ground is frozen thereby disconnecting the subsurface from atmospheric interaction. These findings also suggest ground-gas flux to constitute more risk in summer and autumn than in winter and spring (Nwachukwu and Nwachukwu, 2020).

Most of the observed irregular recovery of $\mathrm{CO}_{2}$ concentration could majorly be due to its low concentrations in the investigated sites (Nwachukwu and Anonye, 2013). The low concentrations of $\mathrm{CO}_{2}$ can be traced to the depths of the monitored boreholes which are mostly deep. This can be explained by the fact that the more $\mathrm{CH}_{4}$ is produced in deep boreholes, due to their anaerobic nature, the more $\mathrm{CO}_{2}$ is produced in shallow boreholes due to their aerobic condition (Holden, 2005; Nwachukwu et al., 2019). This might be the reason for the high concentrations of $\mathrm{CH}_{4}$. Furthermore, landfills are generally known to produce more $\mathrm{CH}_{4}$ than $\mathrm{CO}_{2}$ concentrations (Haro et al., 2019; Zhang et al., 2019).

The recovery profiles (Figures $5-11$ ) of the gases for three purge and recovery tests show that the gases were reproducible; however, this was not consistent throughout the tests. Generally, unlike $\mathrm{CO}_{2} ; \mathrm{CH}_{4}$ concentration was the most reproducible among the investigated gases. This further supports our earlier discovery on the effect of borehole depth on the rate of production and therefore recovery of $\mathrm{CH}_{4}$ and $\mathrm{CO}_{2}$ concentration. Moreover, the gases were more reproducible in June (summer) than in September (autumn) thereby validating our earlier finding that ground-gas recovery rate can vary from season to season and from site to site.

The recovery profiles of VOC (Figures 7 and 11) show VOC concentration to recover in no time unlike that of $\mathrm{CH}_{4}$ and $\mathrm{CO}_{2}$. This could be due to the inherent ability of VOC to volatilize into the atmospheric conditions under normal temperature and pressure as validated by the works of Katy et al., (2009) and Mentero-Mentoya et al., (2018). This property of VOC makes it the most dangerous among the studied gases as it can get to the receptor faster than other gases. The concentrations of recovered VOCs were observed to be generally low and therefore validate findings in literature (Katy et al., 2009; Musbau, 2009; Nwachukwu and Ugwuanyi, 2012; Nwach-ukwu and Uwa, 2018; Zhang et al., 2019; Talbot and Card, 2019).

\section{CONCLUSIONS}

Purge and recovery tests to determine the recharge rate of ground-gases were not always completed within the length of a site visit (one day). This is because, sometimes, it took more than a day for the ground-gases to recover. Ground-gas recovery rate varied from season to season and from site to site. Apart from a change in season, another factor that could be responsible for variation in the recharge rate of the gases is the rate of gas production.

The purge and recovery test to determine whether ground-gas concentrations are reproducible were completed within the length of the site visit. The recovery profiles obtained from the tests varied enormously from borehole to borehole and in general, the VOC recovery profiles observed were very different from those of $\mathrm{CH}_{4}$ and $\mathrm{CO}_{2}$. For example, in borehole 1 , the purge and recovery tests of $\mathrm{CH}_{4}$ and $\mathrm{CO}_{2}$ show similar recovery profiles to those of methane and carbon dioxide shown in the literature (Boult et al., 2011). However, the reproducibility of the tests is questionable as it was observed that the recovery profiles of the two gases for tests 1 are of greater magnitude than their recovery profiles in tests 2 and 3 . This, however, could be due to the flushing of a system of gas by test 1 giving lower concentrations in the recovery profile for tests 2 and 3 as was also observed by Boult et al., (2011).

The recovery profiles of VOCs have no resemblance to those of $\mathrm{CH}_{4}$ and $\mathrm{CO}_{2}$ as VOC concentration generally recovered much faster than their sampling rate. It is, therefore, suggested that the sampling frequency of the Gasclam be increased to match the frequency of recovery of VOCs. The time it took each of the VOC's recovery tests to go down to zero is in order of test $1>$ test $2>$ test 3 (Fig. 1). This suggests that VOC concentration in borehole 1 is low. This also might be the reason they showed no recovery in borehole 2, given the proximity of the two boreholes $(\sim 2$ meter apart). Therefore, the irreproducibility of VOCs in the boreholes may not be unconnected with their trace availability. 


\section{ACKNOWLEDGEMENT}

The authors gratefully acknowledge Ebonyi State Government of Nigeria (Grant Number: EBSG/SSB/FSA/040/VOL. VIII/046) for funding this work.

\section{REFERENCES}

ACUMEN and GGS. 2018. Reducing the climate change impact of landfill gas. The Copper Room, Deva Centre, Trinity Way, M3 7BG, UK. https://www.ggs-uk.com/acumen-ggs/

ASHRAF, M.A., M.J. MAAH AND I. YUSOFF. 2014. Soil contamination, risk assessment and remediation. In: Hernandez Soriano M.C (ed) Environmental risk assessment of soil contamination. Intech Rijeka, 3-56.

BOUCHER, O., P. FRIEDLINGSTEIN, B. COLLINS, K.P. SHINE. 2009. The indirect global warming potential and the global temperature change due to methane oxidation. Environmental research letters, 4:044007.

BOULT, S., P. MORRIS AND S. TALBOT. 2011. The utility of continuous monitoring in detection and prediction of worst case. CL: AIRE bulletin, RB 13. [Available online] URL:http://www.groundgassolutions.co.uk

BOYLE, R. AND P. WITHERINGTON. 2007. Guidance on evaluation of development proposals on sites where methane and carbon dioxide are present. Report Edition: No. 04. National House Building Council, Amersham, UK.

BS 8576:2013. Guidance on investigations for ground gas-permanent gases and volatil organic compounds (VOCs). Published by BSI Standards Limited.

FELICE, M., N. DE SIEYES, J. PENG, R. SCHMIDT, M. BUELOW, K. JOURABCHI, P. SCOW AND D. MACKAY. 2018. Methane transport during a controlled release in the Vaduz's zone. VA dose Zone Journal, 17 (1): 1-11.

FEUYIT, G., S. NZALI, J.N. LAMBI AND S. LAMINSI. 2019. Air quality and human health risk assessment in the residential areas at the proximity of the Nkolfoulou landfill in Yaoundé Metropolis, Cameroon. Journal of Chemistry, 2019, 1-9.

FRIEDRICH, E. AND C. TROIS. 2011. Quantification of greenhouse gas emissions from waste Management processes for municipalities a comp-arative review focusing on Africa. Waste Management, 31, $1585-96$

GAL F., Z. POKRYSZKA, N. LABAT, K. MICHEL, S. LAFORTUNE AND A. MARBLE. 2019. Soilgas concentrations and flux monitoring at the Lacrosse $\mathrm{CO}_{2}$-Geological storage pilot Site (French Pyrenean Forland): from pre-injection to postinjection. Applied Sciences, 9, 645.

HARO, K., I. OUARMA, B. NANA, A. BERE, G.C. TUBREOUMYA, S.Z. KAM, P. LAVILLE, B. LOUBET AND J. KOULIDIATI. 2019. Assess- ment of $\mathrm{CH}_{4}$ and $\mathrm{CO}_{2}$ surface emissions from Poles go's landfill based on static chamber method. Advances in Climate Change Research, 10(3): 181191.

HILLEL, D. 2005. Encyclopaedia of soils in the environment (volumes 1-4). Elsevier, Oxford, UK. Pp. 435-442.

HOLDEN, J. 2005. Pearland hydrology and carbon release: why small-scale process matters. Phil.Trans. R. Soc. A., 363, 2891-2913.

JEWELL, C. AND S. HALLAM. 2012. Guidelines for the assessment and management of sites impacted by hazardous ground gases. NSW Environmental Protection Agency, 59 Goulburn Street, Sydney PO Box A290, Sydney South NSW 1232. pp. 1-94.

KATY, B., H. HELEN, P. LARA, B. DON AND M. CECILIA. 2009. The VOCs handbook: investigation, assessing, and managing risks from inhalation of VOCs at land affected by contamination. CIRIA Report 766, London UK.

LEVINTAL, E., M.I. DRAGILA, H. ZAFRIR AND N. WEISBROD. 2020. The role of atmospheric condition in $\mathrm{CO}_{2}$ and radon emissions from an abandoned water well. Science of the Total environment, 722, 137857.

MENTERO-MONTOYA, R., V. R. LOPEZ AND A.O. ARELLANO. 2018. Volatile organic compounds in air: sources, distribution, exposure and associated illness in children. Annals of Global Health, 84(20): 225-238.

MORRIS, P., M. TODMAN AND S. BOULT. 2008. Improved ground-gas risk prediction using inborehole gas monitoring (IRPIGM). Land Remediation Yearbook. pp. 33-36.

MUSBAU, A.B. 2009. Demonstrating the utility of continuous monitoring to remedy the flaws in spot sampling of ground gas. Unpublished M.Sc. Dissertation. The University of Manchester, United Kingdom, Pp. 38-42.

NAGAMORI, M., M.I.M. MOWJOOD, Y. WATANABE, Y. ISOBE, T. ISHIGAKI AND K. KAWAMOTO. 2016. Characterization of temporal variations in landfill gas components inside an open solid waste dump site in Sri Lanka. Journal of the Air \& Waste Management Association, 66(12):1257-1267.

NWACHUKWU, A. N. AND D. ANONYE. 2013. The effect of atmospheric pressure on methane and carbon dioxide emission from a closed landfill in Manchester, United Kingdom. Environmental Monitoring and Assessment, 185(7): 5729-5735.

NWACHUKWU, A.N. AND J.U. UGWUANYI. 2012. How to improve prediction of risk from ground volatile organic compounds (VOCs) using inborehole gas monitoring. ARPN Journal of Science and Technology, vol. 2, Special Issue, ICESR 2012, pp. $175-183$.

NWACHUKWU, A. N., G.U. SIKAKWE AND A. OTELE. 2018. In-borehole monitoring of greenhouse gas fluxes from upland peat. Middle-East 
Journal of Scientific Research, 26 (3): 370-377.

NWACHUKWU, A.N. AND C.U. UWA. 2018. The utility of a dual monitoring methodology to determine concentration of specific VOCs at high temporal resolution. Middle-East Journal of Scientific Research, 26 (3): 378-394.

NWACHUKWU A.N., A.O. ADEBOJE AND C.U. UWA. 2019. The quantification of $\mathrm{CH} 4$ and $\mathrm{CO}_{2}$ concentrations at different depths in a landfill site and two peat soils. World Applied Sciences Journal, 37 (5): 387-391.

NWACHUKWU, A.N. AND N.V. NWACHUKWU. 2020. Water table: the dominant control on $\mathrm{CH}_{4}$ and $\mathrm{CO}_{2}$ emission from a closed landfill site. Advances in Environmental Research, 9 (2):123-133.

SPARKS, D.L. 2003. The chemistry of saline and sodic soil. Editor: Sparks D.L., Environmental Soil Chemistry (2nd Edition), Academic Press, pp. 285300.

TEASDALE, C.J., J.A. HALL, J.P. MARTIN AND D.A.C. MANNING. 2014. Ground gas monitoring: Implications for hydraulic fracturing and $\mathrm{CO}_{2}$ storage. Environmental Science and Technology, 48, 13610-13616.
TALBOT, S. AND G. CARD. 2019. Continuous ground-gas monitoring and the lines of evidence approach to risk assessment. CL:AIRE Technical Bulletin TB18; London, UK.

WILSON, S., G. CARD, F. COLLINS AND J. LUCAS. 2018. Ground gas monitoring and worst case conditions. CL: AIRE Technical Bulletin 17; CL: AIRE, London, UK.

WILSON, S., F. COLLINS AND L. PHILLIPS. 2017. Complete continuous monitoring in under floorvoids. CL: AIRE Technical Bulletin 16; CL: AIRE, London, UK.

WILSON, S. AND G. CARD. 1999. Reliability and risk in gas protection design. Ground Engineering, $32(2): 33-36$.

WILSON, S., S. OLIVER, H. MALLETT, H. HUTCHINGS AND G. CARD. 2006. Assessing risks posed by hazardous ground gases in buildings. CIRIA Report 669, CL:AIRE, London, UK.

ZHANG C., T. XU, H. FENG AND S. CHEN. 2019. Greenhouse gas emissions from landfills: areview and bibliometric analysis. Sustainability, 11, 2282. 